\title{
Low-density polyethylene films incorporated with silver nanoparticles to promote antimicrobial efficiency in food packaging
}

\author{
Sabrina da Costa Brito ${ }^{1,2} \oplus$, Joana D Bresolin ${ }^{2}$, Kátia Sivieri ${ }^{1}$ and \\ Marcos D Ferreira ${ }^{1,2}$
}

\begin{abstract}
Technological innovations in packaging are intended to prevent microbiological contaminations for ensuring food safety and preservation. In this context, researchers have investigated the antimicrobial effect of lowdensity polyethylene films incorporated with the following concentrations of silver nanoparticles: $1.50,3.75$, $7.50,15.00,30.00,60.00$, and $75.00 \mu \mathrm{g} / \mathrm{ml}$. The films were characterized using field emission gun scanning electron microscopy, Fourier transform infrared spectroscopy, X-ray diffraction, thermogravimetry, and differential scanning calorimetry. From the results of these techniques, it could be concluded that the silver nanoparticles incorporated in the low-density polyethylene films did not influence their physical, chemical, and thermal properties. The direct contact assays, shake-flask assays, and bacterial images obtained using scanning electron microscopy were used to analyze the antimicrobial activity of the films. In the microbial analyses, it was verified that the nanostructured films exhibited antimicrobial properties against all the microorganisms studied, although more notably for fungi and Gram-negative bacteria than the Gram-positive bacteria. Moreover, it was discovered that the packages, in which silver nanoparticles were incorporated, inhibited the growth and reproduction of bacterial cells during the early stages. These results suggest that the extruded low-density polyethylene films incorporated with silver nanoparticles may be an essential tool for improving food quality and safety.
\end{abstract}

\section{Keywords}

Polyethylene, silver nanoparticles, antimicrobial, food packaging

Date received: 24 March 2019; accepted: 6 November 2019

\section{INTRODUCTION}

Packaging materials are mainly intended to protect food against spoilage processes due to chemical, physical, or biological contaminations and oxidation from storage until final consumption to maintain the characteristics of the food for a more extended post-processing period (Gava et al., 2008; Piringer and Baner, 2000; Wróblewska-Krepsztul et al., 2018; Youssef and El-Sayed, 2018).

Food Science and Technology International 0(0) 1-14

(C) The Author(s) 2019 Article reuse guidelines:

sagepub.com/journals-permissions

DOI: $10.1177 / 1082013219894202$

journals.sagepub.com/home/fst

๑SAGE
In this context, technological innovations with respect to advanced and multifunctional packaging are intended to optimize the prevention of food contamination, particularly those arising from microorganisms, leading to enhanced food safety and preservation (Akter et al., 2018; Brody et al., 2008; Carbone et al.,

\footnotetext{
${ }^{1}$ School of Pharmaceutical Sciences, São Paulo State University (UNESP), Araraquara, Brazil

${ }^{2}$ Brazilian Agricultural Research Corporation (EMBRAPA), Embrapa Instrumentation, São Carlos, Brazil

Corresponding author:

Sabrina da Costa Brito, School of Pharmaceutical Sciences, São Paulo State University (UNESP), Rodovia Araraquara Jaú, Km 01-s/n-Campos Ville, Araraquara 14801-902, Brazil.

Email: scbrito@yahoo.com.br
} 
2016; Marsh and Bugusu, 2007; Mihindukulasuriya and Lim, 2014; Wróblewska-Krepsztul et al., 2018).

Nanotechnology applied to food packaging has been searching for alternatives that had been previously considered to be obstacles, as nanotechnology can be used to prepare antimicrobial agents for increasing the shelf life of foods during storage and distribution (Chaudhry et al., 2008; Youssef and El-Sayed, 2018). As a consequence, a new active and intelligent packaging generation, which comprises metal nanoparticle-containing nanostructured packaging, has emerged to reduce the microbial load of food products (Greiner, 2009).

The metal nanoparticles' feature improved antimicrobial efficiency due to their increased surfacearea-to-volume ratio (Damm et al., 2005). Among these, the silver nanoparticles (AgNPs) demonstrate the most intense antimicrobial activity (Akter et al., 2018; Kim et al., 2007; Ruparelia et al., 2008; Siddiqi et al., 2018; Sondi and Salopek-Sondi, 2004). They are also one of the substances that are more frequently combined with polymer-based materials (Becaro et al., 2015; Dehnavi et al., 2012; Jokar et al., 2012) owing to their unique properties, such as high thermal stability and chemical compatibility with polymer matrices of low-density polyethylene (LDPE), which are not observed in other antimicrobial agents (Carbone et al., 2016; Chen and Schluesener, 2008; Duncan, 2011; Jokar et al., 2012).

LDPE is a polymer that is typically used in various economic segments within the food industry because it is flexible, transparent, processible, and thermally stable (Del Nobile et al., 2009; Marsh and Bugusu, 2007). Becaro et al. (2015) observed a stronger antimicrobial activity of silver nanocomposite LDPE films against Staphylococcus aureus and Escherichia coli by conducting the Japanese Industrial Standard test (JIS), and Jokar et al. (2012) also noticed a significant antimicrobial activity of AgNPs + LDPE against S. aureus, E. coli, and Candida albicans through a disk diffusion test. Using fresh-cut carrots packaged with silver nanoparticles incorporated in LDPE, Becaro et al. (2016) verified the antibacterial capability in lower concentrations of AgNPs against mesophilic aerobic and coliforms. These films also maintained the ascorbic acid content of fresh-cut carrots with minimal weight loss. Moreover, Emamifar et al. (2011) observed a significant decrease in fungi and total bacteria populations along with a reduced browning index and improved ascorbic acid retention in orange juice that is packaged in silver nanocomposite films.

In this work, LDPE films with varying concentrations of silver nanoparticles were prepared. Field emission gun scanning electron microscopy (FEG-SEM), Fourier transform infrared (FTIR) spectroscopy, $\mathrm{X}$-ray diffraction (XRD), and thermal analyses were employed to characterize these films. The antimicrobial action of these films was evaluated by direct contact assay, shake-flask assay, and bacterial images obtained from scanning electron microscopy (SEM), aiming to generate widespread applications of this material in food packaging.

\section{MATERIALS AND METHODS Materials}

LDPE-based masterbatch, which comprises AgNPs in concentrations of $1.50,3.75,7.50,15.00,30.00,60.00$, and $75.00 \mu \mathrm{g} / \mathrm{ml}$, was dispersed within a silica $\left(\mathrm{SiO}_{2}\right)$ matrix in the LDPE film (Table 1). The AgNP-free LDPE film was used as the control film. The masterbatches were obtained from a nanotechnology company, and the films were produced in a plastic packaging factory. Both companies are based in São Paulo, Brazil.

\section{Film preparation}

The masterbatches and pure LDPE pellets (LDPE 583) were mixed in plastic bags for $3 \mathrm{~min}$ in distinct concentrations (Table 2) and extruded in films by a plastic benchtop single screw extruder (AX Plastic). These mixtures were added to the extruder that comprises three different heating zones at $160^{\circ} \mathrm{C}$ (zone 1), $145^{\circ} \mathrm{C}$ (zone 2), and $130^{\circ} \mathrm{C}$ (zone 3) and operates at a screw speed of $35 \mathrm{r} / \mathrm{min}$ (Becaro et al., 2015).

\section{Film characterization}

FEG-SEM. The morphological characteristics of the AgNP-containing films were investigated by detecting backscattered electrons through FEG-SEM using a JSM-6701F/JEOL microscope. Films were sectioned and fixed in stubs for obtaining the surface images. For cross-sectional images, films were cryo-fractured

Table 1. Percentage per masterbatch (\%) for varied AgNP and $\mathrm{SiO}_{2}$ content concentrations $(\mu \mathrm{g} / \mathrm{ml})$

\begin{tabular}{|c|c|c|}
\hline $\begin{array}{l}\text { Masterbatch } \\
\text { (\%) }\end{array}$ & $\begin{array}{l}\text { AgNP } \\
\text { concentration } \\
(\mu \mathrm{g} / \mathrm{ml})\end{array}$ & $\begin{array}{l}\mathrm{SiO}_{2} \\
\text { concentration } \\
(\mu \mathrm{g} / \mathrm{ml})\end{array}$ \\
\hline 2 & 1.50 & 298.50 \\
\hline 5 & 3.75 & 746.25 \\
\hline 10 & 7.50 & 1492.50 \\
\hline 20 & 15.00 & 2985.00 \\
\hline 40 & 30.00 & 5970.00 \\
\hline 80 & 60.00 & $11,940.00$ \\
\hline 100 & 75.00 & $14,925.00$ \\
\hline
\end{tabular}


Table 2. AgNP concentration in LDPE film $(\mu \mathrm{g} / \mathrm{ml})$ for each percentage compositional ratio between masterbatch and LDPE (\%)

\begin{tabular}{lr}
\hline $\begin{array}{l}\text { AgNP } \\
\text { concentration } \\
(\mu \mathrm{g} / \mathrm{ml})\end{array}$ & $\begin{array}{l}\text { Masterbatch: } \\
\text { LDPE }(\%)\end{array}$ \\
\hline 1.50 & $2: 99.99970$ \\
3.75 & $5: 99.99925$ \\
7.50 & $10: 99.99850$ \\
15.00 & $20: 99.99700$ \\
30.00 & $40: 99.99400$ \\
60.00 & $80: 99.98800$ \\
75.00 & $100: 99.98500$ \\
\hline
\end{tabular}

LDPE: low-density polyethylene.

in liquid nitrogen and fixed similarly. The samples were then carbon-coated on an evaporator and imaged. Moreover, the $\mathrm{Ag}+\mathrm{SiO}_{2}$ powder additive was also analyzed.

FTIR spectroscopy. The FTIR spectrometer Perkin Elmer, model Spectrum 1000, was used to detect vibrational frequencies. Control and nanostructured specimens were analyzed using 64 scans at wavenumbers ranging from 4000 to $400 \mathrm{~cm}^{-1}$ with a resolution of $4 \mathrm{~cm}^{-1}$. Film specimens without prior preparation were attached to the support, and the FTIR spectra were recorded using the transmittance method.

$X R D$. A Shimadzu diffractometer model 6000 was used to determine the atomic structures of the films and $\mathrm{Ag}+\mathrm{SiO}_{2}$ powder additive, in which control and nanostructured samples without prior treatments were attached using a standard glass holder. Once in the $\mathrm{X}$-ray generation chamber, the samples were analyzed at a $30 \mathrm{kV}$ acceleration voltage, $30 \mathrm{~mA}$ current, $0.5^{\circ}$ per $\min ^{-1}$, and $2 \theta$ ranging between $4^{\circ}$ and $90^{\circ}$.

Thermal analyses. Thermogravimetry (TG) was used to investigate the thermal stability of the film. A thermogravimetric analyzer TGA Q 500 (TA Instruments) was used to analyze the samples $(10 \mathrm{mg})$ at a heating rate of $10^{\circ} \mathrm{C} / \mathrm{min}$ from 10 to $800^{\circ} \mathrm{C}$. Nitrogen and synthetic air flows were provided at 40 and $60 \mathrm{ml} / \mathrm{min}$, respectively.

To identify the endothermic and exothermic events in the $10 \mathrm{mg}$ film samples upon heating, a DSC Q 100 (TA Instruments) was used for differential scanning calorimetry (DSC) runs. Tests were conducted at temperatures ranging from 10 to $200^{\circ} \mathrm{C}$, using a heating rate at $10^{\circ} \mathrm{C} / \mathrm{min}$ in a nitrogen atmosphere flowing at $60 \mathrm{ml} / \mathrm{min}$.

\section{Microbiological evaluations}

Direct contact assays, shake-flask assays, and bacterial images were obtained by performing SEM on the Gram-positive bacteria $S$. aureus (INCQS 15 ATCC 25923) and Enterococcus faecalis (INCQS 234 ATCC 29212), Gram-negative bacteria E. coli (INCQS 33 ATCC 25922) and Salmonella enterica subsp. enterica serovar Typhimurium (INCQS 84 ATCC 13311), and apple-isolated Penicillium expansum (PEN001). The AgNP-free LDPE films were used as the control in all these tests. The antibiotic streptomycin sulfate (SigmaAldrich) $(3000 \mu \mathrm{g} / \mathrm{ml})$ was used as the positive control for $S$. aureus, S. Typhimurium, and Escherichia, whereas levofloxacin (Novartis) $(0.25 \mu \mathrm{g} / \mathrm{ml})$ and the antifungal itraconazole (EMS) $(16 \mu \mathrm{g} / \mathrm{ml})$ were used as positive controls for E. faecalis and $P$. expansum, respectively.

Direct contact assay. Bacterial colonies were inoculated in $10 \mathrm{ml}$ of tryptic soy broth (TSB) (Kasvi) and incubated at $37^{\circ} \mathrm{C}$ for $24 \mathrm{~h}$. Then, each microorganism was centrifuged (Hettich Zentrifugen Rotina-390) for $5 \mathrm{~min}$ at $10^{\circ} \mathrm{C}$ and $2000 \mathrm{r} / \mathrm{min}$. The supernatant was discarded, and the cells were re-suspended in the saline solution $(0.9 \%)$. Each microorganism inoculum was adjusted to provide a final concentration of $1.14 \times 10^{5} \log \mathrm{CFU} / \mathrm{ml}$ for $S$. aureus, $0.58 \times 10^{5} \log$ $\mathrm{CFU} / \mathrm{ml}$ for E. faecalis, $1.12 \times 10^{5} \log \mathrm{CFU} / \mathrm{ml}$ for E. coli, and $1.03 \times 10^{5}$ for $S$. Typhimurium in $\log$ $\mathrm{CFU} / \mathrm{ml}$ through absorbance readings at $600 \mathrm{~nm}$ on an ultraviolet-visible (UV-VIS) spectrometer (Shimadzu UV 1650) (Pagno et al., 2015).

The control and AgNP-containing films were shaped into $4 \mathrm{~cm} \times 4 \mathrm{~cm}\left(16 \mathrm{~cm}^{2}\right)$ squares, disinfected by immersing in $70 \%$ ethyl alcohol for $15 \mathrm{~min}$, and accommodated in the inner wall of Eppendorf tubes, where $500 \mu \mathrm{l}$ of microbial suspension was subsequently added. The microorganisms were then incubated under gentle shaking $(150 \mathrm{r} / \mathrm{min})$ in a rotary incubator (Tecnal-TE 4200 ) for $24 \mathrm{~h}$ at room temperature $\left( \pm 25^{\circ} \mathrm{C}\right.$ ) (Pagno et al., 2015).

As for the $P$. expansum, the stock culture grown in potato dextrose agar (PDA) (Kasvi) for seven days was suspended by adding sterilized Tween 80 solution $(0.1 \% \mathrm{v} / \mathrm{v})$ and scraped with a Drigalski loop to remove further spores to achieve a concentration of $0.72 \times 10^{4} \log \mathrm{CFU} / \mathrm{ml}$. It was then adjusted on a Neubauer (Kasvi) chamber using the saline solution $(0.9 \%)$ (Avila-Sosa et al., 2010).

A $100 \mu 1$ microbial suspension aliquot was then withdrawn from each tube and transferred to an Eppendorf containing $900 \mu \mathrm{l}$ of $0.9 \%$ saline solution, followed by serial dilutions, while each of these solutions was vigorously vortexed. From each dilution, $10 \mu \mathrm{l}$ of the microbial solution was seeded onto a tryptic soy agar 
(Kasvi) or PDA medium (for $P$. expansum) and incubated at $37^{\circ} \mathrm{C}$ for $24 \mathrm{~h}$ for Gram-negative bacteria. The incubation was performed at $37^{\circ} \mathrm{C}$ for $48 \mathrm{~h}$ and $25^{\circ} \mathrm{C}$ for $72 \mathrm{~h}$ for Gram-positive bacteria and $P$. expansum, respectively. Viable cells in each of the previously inoculated Petri dishes were counted to quantify the colony formation (Avila-Sosa et al., 2010; Pagno et al., 2015).

Shake-flask assay. The control and AgNP-containing films were shaped into eight $2 \mathrm{~cm} \times 1.5 \mathrm{~cm}\left(3 \mathrm{~cm}^{2}\right)$ rectangles and disinfected by immersing in $70 \%$ ethyl alcohol for $15 \mathrm{~min}$ before being dipped in $100 \mathrm{ml}$ of TSB (Jokar et al., 2012).

Each bacterium $(1 \mathrm{ml})$ was inoculated into $200 \mathrm{ml}$ Erlenmeyer flasks containing TSB, test specimens, and $0.4 \mathrm{~g}$ of Tween 80 to achieve a final concentration of $1.13 \times 10^{5} \log \mathrm{CFU} / \mathrm{ml}$ for $S$. aureus, $1.23 \times 10^{5} \log$ $\mathrm{CFU} / \mathrm{ml}$ for $E$. faecalis, $1.14 \times 10^{5} \log \mathrm{CFU} / \mathrm{ml}$ for E. coli, and $1.10 \times 10^{5}$ for $S$. Typhimurium in $\log$ $\mathrm{CFU} / \mathrm{ml}$. After this process, the flasks were incubated under stirring at $150 \mathrm{r} / \mathrm{min}, 37^{\circ} \mathrm{C}$, and $26 \mathrm{~h}$. Microbial growth was monitored with absorbance readings at $600 \mathrm{~nm}$ on a UV-VIS spectrometer using samples withdrawn every $2 \mathrm{~h}$ during $14 \mathrm{~h}$; after this period, 24 and $26 \mathrm{~h}$ samples were also collected (Jokar et al., 2012).

Bacterial images from SEM. The SEM was conducted using a JSM-6701F/JEOL microscope to observe the antimicrobial activity of nanostructured films against Gram-positive $S$. aureus $\left(1.08 \times 10^{7} \log \mathrm{CFU} / \mathrm{ml}\right)$ and Gram-negative E. coli $\left(1.36 \times 10^{6} \log \mathrm{CFU} / \mathrm{ml}\right)$. The bacteria were initially added to the direct contact antimicrobial assay without serial dilutions. Ten microliters of the bacterial suspension was placed in the center spot of a microscopy slide previously coated with $0.1 \%$ poly-L-lysine solution. The slides were placed in Eppendorf flasks, which were then filled with Karnawesk solution for $4 \mathrm{~h}$. Then, the samples were washed with cacodylate buffer and distilled water and dehydrated with $30 \%$ (10 $\mathrm{min}), 50 \%$ (10 min), $70 \%$ (10 $\mathrm{min}$ ), $90 \%$ (10 min), and $100 \%$ (three times for $10 \mathrm{~min}$ each) acetone solutions. The samples were freeze-dried (Liotop L 101) according to the manufacturer's instructions for $24 \mathrm{~h}$ and retained in a desiccator until they were fixed onto stubs and gold-sputtered (Spricigo et al., 2015).

\section{Statistical analysis}

The analysis of variance (ANOVA) and Games-Howell multiple comparisons test were performed to evaluate the number of colonies concerning different AgNP concentrations in the direct contact antimicrobial assay, as
Bartlett's test indicated heterogeneity among variances. For the shake-flask antimicrobial assay, the variables were compared by ANOVA in addition to performing Duncan's multiple range test and Kruskal-Wallis test, respectively, for homogenous and heterogeneous samples on the variances resulting from Bartlett's test. All statistical procedures were conducted using the R software version 3.3 .3 at a significance level of $5 \%$. All microbiological evaluations were performed in triplicate.

\section{RESULTS AND DISCUSSION}

\section{Film characterization}

FEG-SEM. The images obtained from the backscattered FEG (Figure 1) exhibit light clusters. The gray portions of $\mathrm{Ag}$ and $\mathrm{SiO}_{2}$ dispersed within the film on its surfaces and cross-sections, corroborating with the FEG images of the $\mathrm{Ag}+\mathrm{SiO}_{2}$ powder additive (Figure 2), thereby establishing the nanostructured form of the films.

The images obtained from the backscattered FEG include information on the deepest layers of the samples, which in turn depends on their atomic composition. In other words, because $\mathrm{Ag}$ and $\mathrm{SiO}_{2}$ (which were present in the nanostructured LDPE films) possess a higher atomic number than the other film components, a better contrast is observed in these images (Figure 1) (Canevarolo, 2017), which corroborate the images of the surface of backscattered $\mathrm{FEG} \mathrm{Ag}+\mathrm{SiO}_{2}$ powder additive.

The presence, on the surface and cross-sections of the films, of $\mathrm{Ag}$ and mesoporous silica such as AgNP carrier is of great importance, being that the first is a metal that demonstrates a wide range of bacterial fighting pathogens and is important for the potential antimicrobial properties of these films and the second is an inorganic substrate recognized for its biocompatibility, dispersibility, chemical stability, and ability to provide antimicrobial agents (Franci et al., 2015; Huang et al., 2015; Qasim et al., 2015).

FTIR. The infrared spectra presented in Figure 3 validate that the nanostructured samples demonstrate characteristic bands of pure LDPE. These results are similar to those observed in other studies that compared pure and AgNP-containing LDPE films (Becaro et al., 2015; Puti et al., 2014).

The bands at $719 \mathrm{~cm}^{-1}$ (balance of methylene group sequences), $1369 \mathrm{~cm}^{-1}$ (C-H flexion of methyl groups), $1461 \mathrm{~cm}^{-1}$ (C-H folding of methylene groups), $2848 \mathrm{~cm}^{-1}$ (C-H stretching), and $2916 \mathrm{~cm}^{-1}$ (methylene stretching) corroborate the characteristic LDPE peaks (Mishra and Luyt, 2008; Olmos et al., 2012; Rajandas et al., 2012). 


\section{Brito et al.}
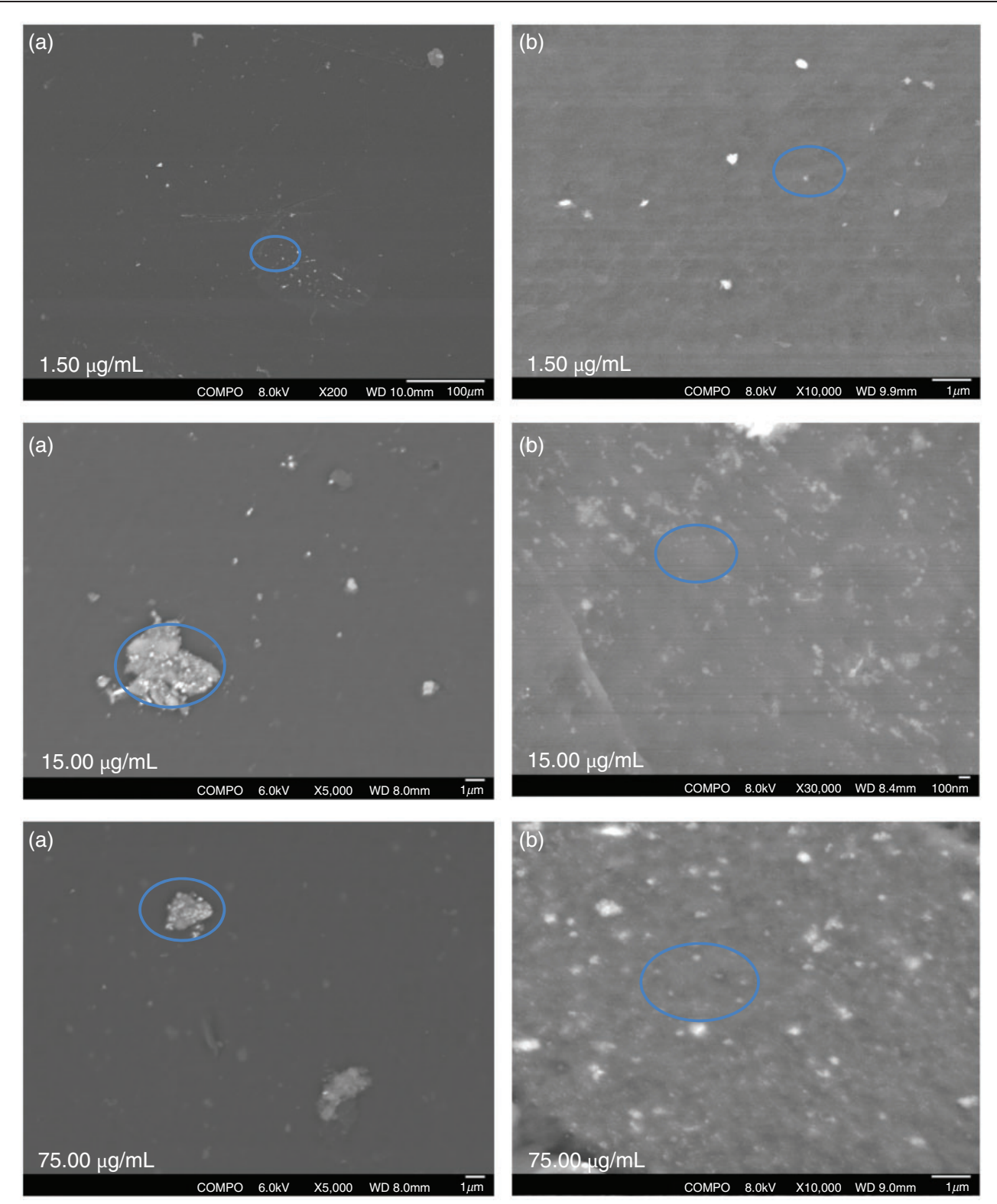

Figure 1. Surface (a) and cross-sectional (b) images, indicating the $\mathrm{Ag}$ and $\mathrm{SiO}_{2}$ clusters obtained from backscattered FEG of nanostructured samples.

Figure 3 also shows peaks at 472 and $1087 \mathrm{~cm}^{-1}$ that are characteristic of $\mathrm{SiO}_{2}$, which are assigned to tetragonal $\mathrm{Si}-\mathrm{O}$ bonds and $\mathrm{Si}-\mathrm{O}-\mathrm{Si}$ group, respectively (Gowri et al., 2011; Lacerda Júnior et al., 2013). Also, it is observed that as the $\mathrm{SiO}_{2}$ concentration increases, there is an increase in the corresponding peaks.

XRD. The XRD patterns of the films (Figure 4) show typical diffraction peaks around $2 \theta=21.56^{\circ}, 24.08^{\circ}$, and $36.50^{\circ}$, which correspond to the orthorhombic structure of polyethylene. Such a pattern is similar to those reported in previous works on LDPE (Miranda and Carvalho, 2011; Motaung et al., 2017; Xia et al., 2006).

The XRD patterns evidence two major crystalline peaks, the most intense in the angular range, which is the Miller index $\left[(110)-22^{\circ}\right]$, and a less intense one $\left[(200)-37^{\circ}\right]$, confirming the semi-crystallinity of polyethylene and characterize LDPE by matching with its specific crystallographic planes (Madani, 2011; Motaung et al., 2017).

There is an increase in the intensity of the peaks corresponding to the 3.75 and $7.50 \mu \mathrm{g} / \mathrm{ml}$ samples. This can be due to the mechanical stretching that may 
have occurred during the processing of the films (LeBourvellec et al., 1986).

It is evident from Figure 4 that only the diffraction peaks of polyethylene are present in all the analyzed samples, indicating that the silica, AgNP carrier, is in its amorphous form, corroborating the absence of silica peaks in the $\mathrm{Ag}+\mathrm{SiO}_{2}$ powder additive. The lack of $\mathrm{Ag}$ in the outcome may be attributed to its low concentration in the samples, i.e. below the detection threshold of the equipment. Becaro et al. (2015) also studied AgNPcontaining LDPE-based films using XRD and did not identify Ag.

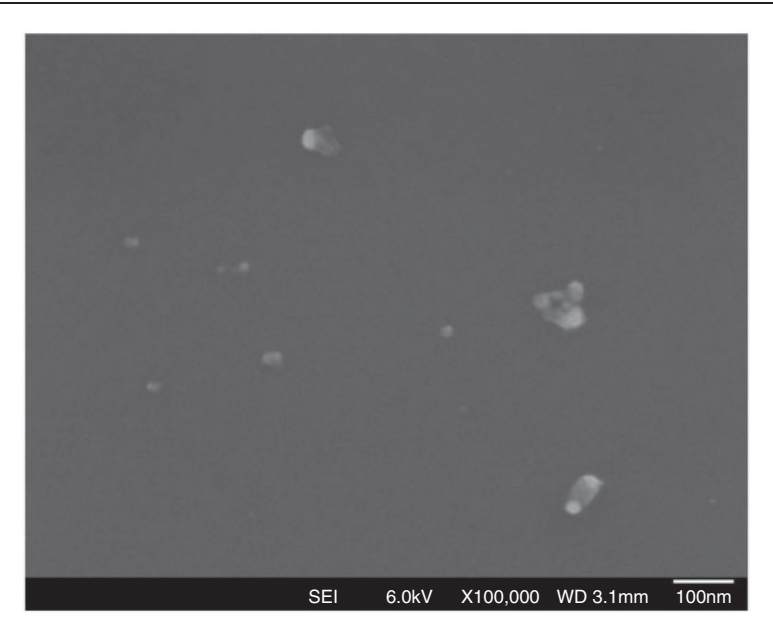

Figure 2. Surface images obtained from backscattered $\mathrm{FEG}$ of $\mathrm{Ag}+\mathrm{SiO}_{2}$ powder additive.
The diffraction peaks corresponding to Ag crystallographic planes are $2 \theta=\left[\begin{array}{lll}(111) & 38.2^{\circ}-39.4^{\circ}\end{array}\right],[(200)$ $44.4^{\circ}-44.6^{\circ}$ ], [(220) $\left.63.5^{\circ}-64.6^{\circ}\right]$, and [(311) $77.6^{\circ}-78.1^{\circ}$ ] (Abdel-Mohsen et al., 2014; Liu et al., 2012).

\section{Thermal analyses}

TG. The nanostructured films exhibit thermal stabilities that are similar to those of the control film (Figure 5), which is better determined from the TG

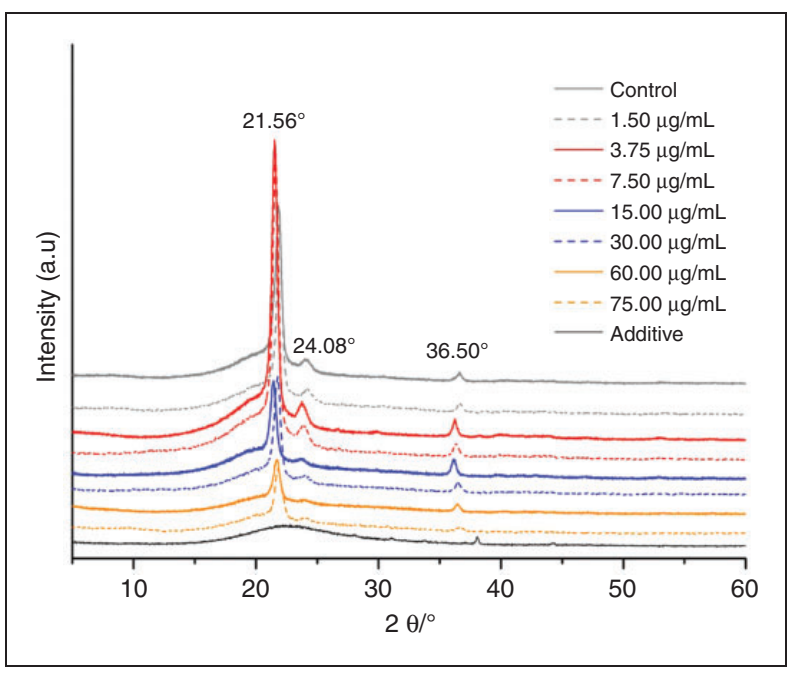

Figure 4. Intensity in arbitrary units (a.u.) versus diffraction angle in degrees $\left(2 \theta /{ }^{\circ}\right)$ for control and nanostructured samples and $\mathrm{Ag}+\mathrm{SiO}_{2}$ powder additive.

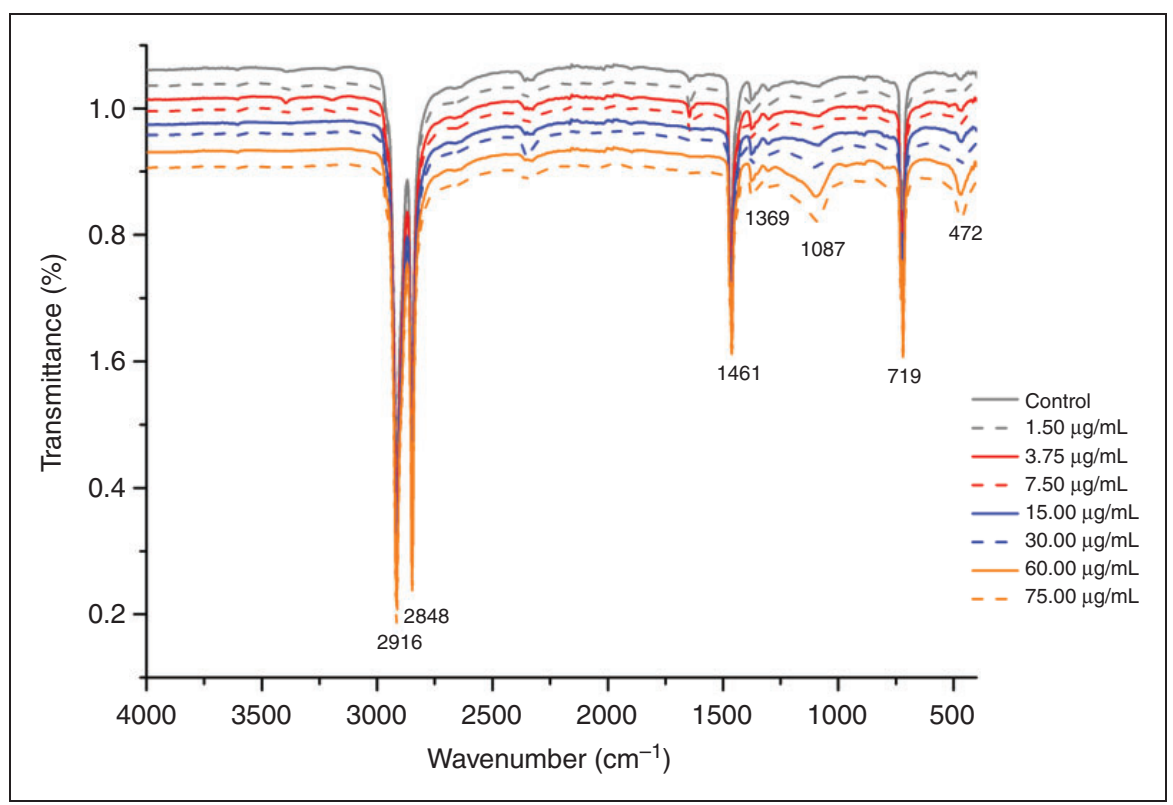

Figure 3. Transmittance (\%) versus wavenumber $\left(\mathrm{cm}^{-1}\right)$ of control and nanostructured samples. 
Brito et al.

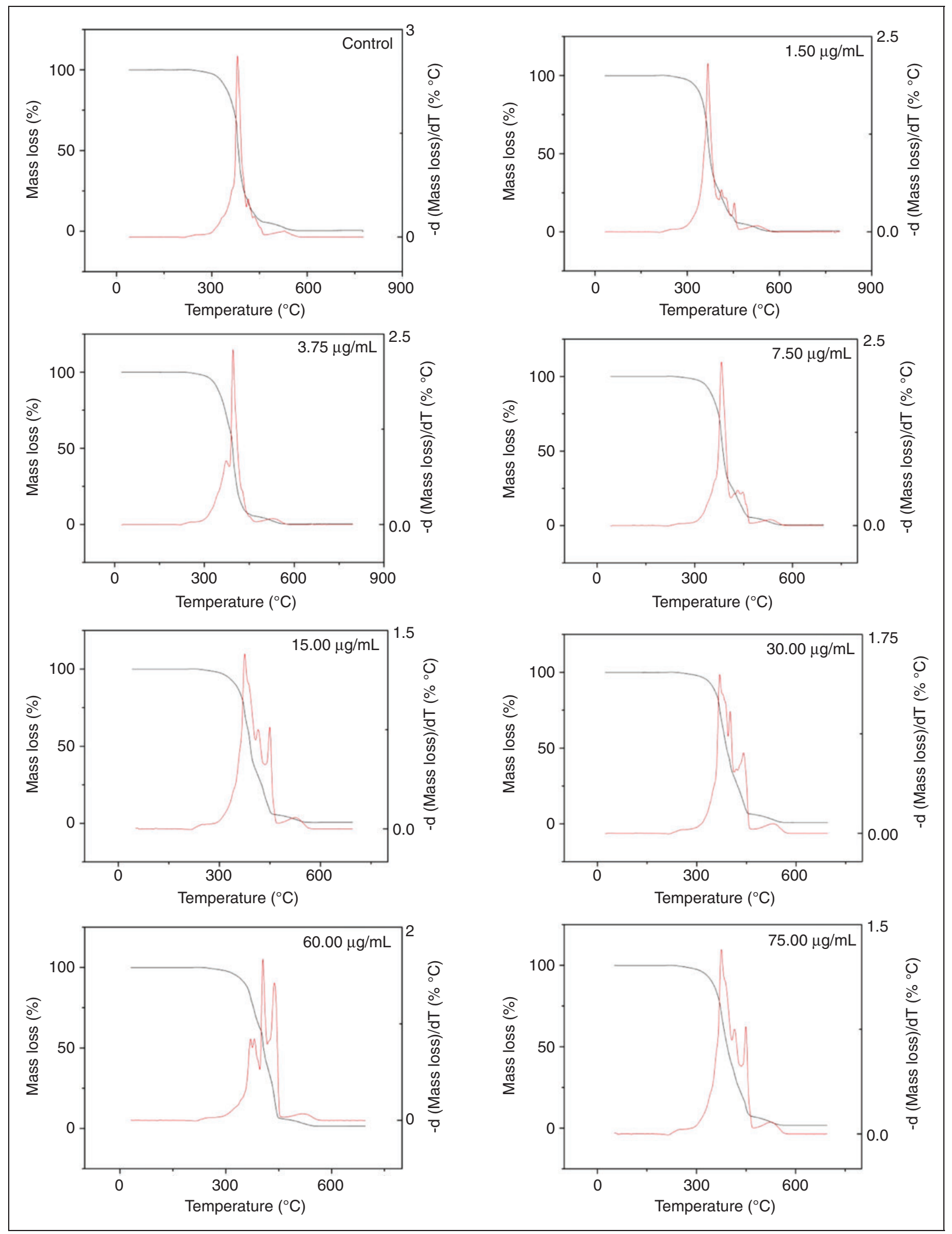

Figure 5. TG analysis and derivative thermogravimetric analysis curves of control and nanostructured samples in a synthetic air atmosphere at $10-800^{\circ} \mathrm{C}$. 
curve than the derivative thermogravimetric analysis. This phenomenon is also evident from the extrapolated onset degradation temperatures $\left(\mathrm{T}_{\text {onset }}\right)$ of the films (Table 3). The $\mathrm{T}_{\text {onset }}$ has marginally declined in most samples when compared to control; however, it has marginally increased for concentrations of 3.75 and $60.00 \mu \mathrm{g} / \mathrm{ml}$; this variation in the thermal stability of the samples may occur due to the distinct characteristics and syntheses between the masterbatch LDPE and the LDPE pellets used to process the films (Becaro et al., 2015). This observation corroborates the data reported by Boschetto et al. (2012), who observed that the addition of Ag-loaded zeolite into LDPE does not cause a significant difference in $\mathrm{T}_{\text {onset }}$ when compared to pristine LDPE.

The nanostructured samples exhibit a $50 \%$ degradation temperature residue $\left(\mathrm{T}_{50 \%}\right)$ values similar to those of the control LDPE. Moreover, the residual percentage at $700{ }^{\circ} \mathrm{C}$ (Table 3) is similar to that of pristine LDPE (control), suggesting a suitable homogeneous polymer system (Becaro et al., 2015).

DSC. The melting temperature $\left(\mathrm{T}_{\mathrm{m}}\right)$ of LDPE obtained from DSC was observed to be similar to the corresponding values reported in previous studies: 107.7, 114, and $124.5^{\circ} \mathrm{C}$ (Boschetto et al., 2012; Motaung et al., 2017; Pérez et al., 2014). Moreover, it was observed that the addition of AgNPs did not promote significant $T_{m}$ variations.

All the films analyzed exhibit endothermic peaks precisely related to the melting point of the polymer matrix, as the degradation temperature of the samples is observed only at higher temperatures (Figure 6). A similar outcome has been reported by Becaro et al. (2015), who compared the $\mathrm{T}_{\mathrm{m}}$ values of pure and AgNP-added LDPE films and indicated no significant

Table 3. Extrapolated onset degradation temperature ( $T_{\text {onset }}$ ), the temperature was corresponding to $50 \%$ degradation $\left(\mathrm{T}_{50 \%}\right)$ and residual percentage at $700^{\circ} \mathrm{C}$ $(R(\%))$ of control and nanostructured samples $(\mu \mathrm{g} / \mathrm{ml})$

\begin{tabular}{llll}
\hline $\begin{array}{l}\text { Concentrations } \\
(\mu \mathrm{g} / \mathrm{ml})\end{array}$ & $\mathrm{T}_{\text {onset }}\left({ }^{\circ} \mathrm{C}\right)$ & $\mathrm{T}_{50 \%}\left({ }^{\circ} \mathrm{C}\right)$ & $\mathrm{R} / 700{ }^{\circ} \mathrm{C}(\%)$ \\
\hline Control & 365.70 & 383.65 & 99.61 \\
1.50 & 349.53 & 372.27 & 99.56 \\
3.75 & 374.33 & 386.40 & 99.74 \\
7.50 & 364.14 & 386.40 & 99.60 \\
15.00 & 362.45 & 391.79 & 99.40 \\
30.00 & 351.64 & 389.94 & 99.20 \\
60.00 & 375.27 & 406.65 & 98.56 \\
75.00 & 354.55 & 393.02 & 98.22 \\
\hline
\end{tabular}

variations in the melting temperature upon the addition of AgNPs (Boschetto et al., 2012).

Some variations are observed in the melting enthalpy $\left(\Delta \mathrm{H}_{\mathrm{m}}\right)$ corresponding to the nanostructured samples (Table 4). The decrease in $\Delta \mathrm{H}_{\mathrm{m}}$ corresponding to samples 30.00 and $60.00 \mu \mathrm{g} / \mathrm{ml}$ and their increase of $\mathrm{T}_{\mathrm{m}}$ when compared to the control film may be attributed to the strong interaction between masterbatch and polymer matrix to achieve a homogeneous distribution. This decreases the molecular mobility upon heating and thus decreases the energy absorbed during the process (Becaro et al., 2015).

\section{Microbiological evaluations}

Direct contact antimicrobial activity. The results obtained from this assay show that the nanostructured films exhibit antimicrobial activity against the tested

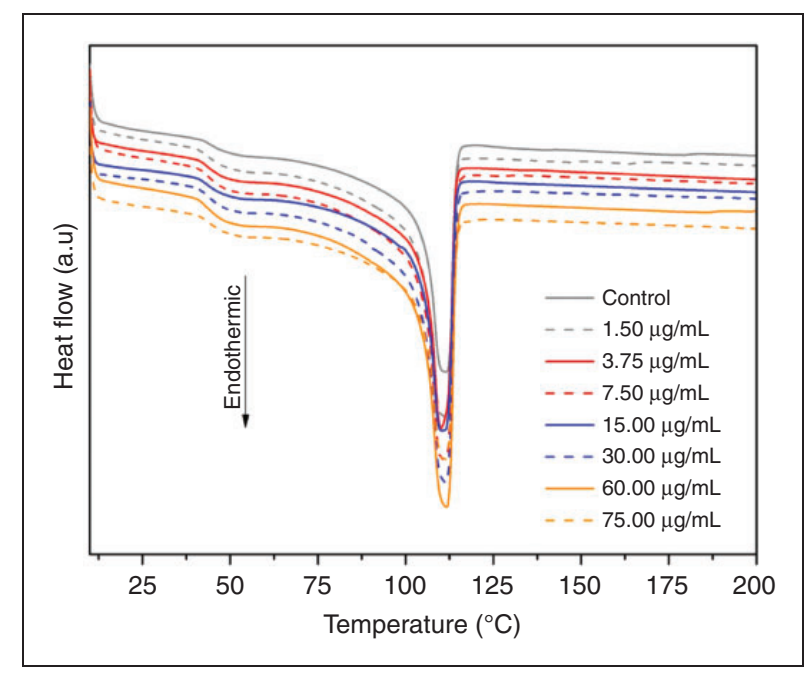

Figure 6. Heat flow (a.u.) versus temperature $\left({ }^{\circ} \mathrm{C}\right)$ of control and nanostructured samples.

Table 4. Melting temperature $\left(T_{m}\right)$ and enthalpy $\left(\Delta H_{m}\right)$ of control and nanostructured samples $(\mu \mathrm{g} / \mathrm{ml})$

\begin{tabular}{lll}
\hline Concentrations $(\mu \mathrm{g} / \mathrm{ml})$ & $\mathrm{T}_{\mathrm{m}}\left({ }^{\circ} \mathrm{C}\right)$ & $\Delta \mathrm{H}_{\mathrm{m}}(\mathrm{J} / \mathrm{g})$ \\
\hline Control & 111.49 & 128.8 \\
1.50 & 111.29 & 125.3 \\
3.75 & 110.07 & 128.6 \\
7.50 & 110.60 & 138.9 \\
15.00 & 110.29 & 133.9 \\
30.00 & 111.57 & 121.4 \\
60.00 & 111.67 & 122.5 \\
75.00 & 110.93 & 125.0 \\
\hline
\end{tabular}


microorganisms (Table 5). It is observed that the log $\mathrm{CFU} / \mathrm{ml}$ of $S$. aureus, E. coli, $S$. Typhimurium, and $P$. expansum decline for AgNP concentrations equal to or higher than $1.50 \mu \mathrm{g} / \mathrm{ml}$, although the differences from the negative control were significant in most of these microorganisms $(p \leq 0.05)$ only from the concentration of $3.75 \mu \mathrm{g} / \mathrm{ml} \mathrm{AgNPs.}$

Total inhibition of $P$. expansum growth was observed in all concentrations of AgNPs in the film. It is important to highlight that $P$. expansum is a significant concern of the global food industry due to its wide occurrence and ability to produce various mycotoxins, of which the most significant is patulin (Tannous et al., 2018).

In the case of E. faecalis, a reduced $\log \mathrm{CFU} / \mathrm{ml}$ at a concentration of $7.50 \mu \mathrm{g} / \mathrm{ml}$ is observed. However, a significant difference $(\mathrm{p} \leq 0.05)$ compared to the negative control is only observed at $75.00 \mu \mathrm{g} / \mathrm{ml}$, suggesting that the highest concentration inhibits this microorganism.

Related to verified results, the antibacterial actions of silver nanoparticles may occur due to:

- Silver nanoparticles provide a large surface area for contact with microorganisms, thus enabling more significant contact between the particles and the cell membrane, facilitating their penetration into microorganisms (Durán et al., 2016; Zhang et al., 2016);

- Silver nanoparticles can impair DNA replication and, consequently, in the respiratory chain, resulting in cell death (Durán et al., 2016);

- Generation of reactive oxygen species (ROS) by silver nanoparticles, contributing to direct damage to a cell membrane (Durán et al., 2016; Zhang et al., 2016).
One of the main mechanisms of action of silver nanoparticles in microorganisms is their cell membrane dissolution, becoming important the species of microorganisms, since the antimicrobial activity of nanoparticles may depend on it (Durán et al., 2016; Zhang et al., 2016); in a research conducted by Kim et al. (2007) founded that the inhibitory effect of silver nanoparticles was more potent in yeast and $E$. coli than $S$. aureus; similar to the results in this research where the inhibitions of Gram-negative bacteria and P. expansum are significantly higher than those of Gram-positive bacteria, related to this we can suggest that the antimicrobial effect of AgNPs could be associated with the characteristics of specific bacterial species (Kim et al., 2007; Ruparelia et al., 2008). Gram-positive and Gramnegative bacteria present different membrane structures, particularly concerning the thickness of the peptidoglycan layer, which has an essential function in the protection of bacterium against antibacterial agents. Gram-positive bacteria feature a thicker peptidoglycan layer than their Gram-negative counterparts, and therefore, the former is more effectively protected against the formation of ruptures in their cell membranes, corroborating the inhibition values observed in this study and some prior studies as well (Kim et al., 2007, 2011; Mirzajani et al., 2011; Ruparelia et al., 2008).

Regarding DNA, silver ions at $\mu \mathrm{mol} / 1$ levels impair replication due to the decoupling of respiratory electron transport from oxidative phosphorylation, which consequently inhibits respiratory chain enzymes and interferes with membrane permeability (Durán et al., 2016).

The accumulation of silver nanoparticles in the microbial membrane generates ROS that can seriously damage cellular components such as proteins, lipids, and nuclear substances, seriously destroying the

Table 5. Mean \pm and standard deviation values of $S$. aureus, E. faecalis, E. coli, S. Typhimurium, and $P$. expansum counts $(\log \mathrm{CFU} / \mathrm{ml})$ of the negative control and nanostructured samples $(\mu \mathrm{g} / \mathrm{ml})$

\begin{tabular}{llllll}
\hline $\begin{array}{l}\text { Concentrations } \\
(\mu \mathrm{g} / \mathrm{ml})\end{array}$ & $\begin{array}{l}\text { S. aureus } \\
(\log \mathrm{CFU} / \mathrm{ml})\end{array}$ & $\begin{array}{l}\text { E. faecalis } \\
(\log \mathrm{CFU} / \mathrm{ml})\end{array}$ & $\begin{array}{l}\text { E. coli } \\
(\log \mathrm{CFU} / \mathrm{ml})\end{array}$ & $\begin{array}{l}\text { S. Typhimurium } \\
(\log \text { CFU/ml) }\end{array}$ & $\begin{array}{l}\text { P. expansum } \\
\text { (log CFU/ml) }\end{array}$ \\
\hline Negative control & $2.210 \pm 1.834^{\mathrm{a}}$ & $1.196 \pm 0.462^{\mathrm{b}}$ & $2.198 \pm 1.322^{\mathrm{a}}$ & $1.809 \pm 1.274^{\mathrm{a}}$ & $0.568 \pm 0.079^{\mathrm{a}}$ \\
1.50 & $2.035 \pm 1.633^{\mathrm{ab}}$ & $1.493 \pm 0.978^{\mathrm{a}}$ & $2.072 \pm 0.623^{\mathrm{b}}$ & $1.625 \pm 0.898^{\mathrm{ab}}$ & $<1$ \\
3.75 & $2.034 \pm 1.635^{\mathrm{ab}}$ & $1.225 \pm 0.845^{\mathrm{bc}}$ & $1.880 \pm 1.243^{\mathrm{c}}$ & $1.535 \pm 0.477^{\mathrm{b}}$ & $<1$ \\
7.50 & $1.828 \pm 1.134^{\mathrm{b}}$ & $1.188 \pm 0.740^{\mathrm{bc}}$ & $1.852 \pm 1.253^{\mathrm{c}}$ & $1.276 \pm 0.875^{\mathrm{c}}$ & $<1$ \\
15.00 & $1.818 \pm 0.556^{\mathrm{b}}$ & $1.179 \pm 0.568^{\mathrm{b}}$ & $1.588 \pm 0.914^{\mathrm{d}}$ & $0.672 \pm 0.079^{\mathrm{d}}$ & $<1$ \\
30.00 & $1.817 \pm 1.068^{\mathrm{b}}$ & $1.104 \pm 0.531^{\mathrm{bc}}$ & $0.845 \pm 0.519^{\mathrm{e}}$ & $0.771 \pm 0.079^{\mathrm{d}}$ & $<1$ \\
60.00 & $1.780 \pm 1.322^{\mathrm{bc}}$ & $0.996 \pm 0.857^{\mathrm{bc}}$ & $0.672 \pm 0.144^{\mathrm{e}}$ & $0.699 \pm 0.505^{\mathrm{d}}$ & $<1$ \\
75.00 & $1.682 \pm 0.398^{\mathrm{c}}$ & $0.934 \pm 0.380^{\mathrm{c}}$ & $0.279 \pm 0.041^{\dagger}$ & $<1$ & $<1$ \\
\hline
\end{tabular}

Mean values followed by the same letter ( $a, b, c, d, e$ or $f$ ) within the same column do not differ significantly, as indicated by Duncan and Kruskal-Wallis (S. Typhimurium) tests $(p>0.05)$. 
Table 6. Mean \pm and standard deviation values of growth rate, maximum concentrations at stationary and lag phases (reported in hours) of S. aureus, E. faecalis, E. coli, and S. Typhimurium of negative control and nanostructured samples $(\mu \mathrm{g} / \mathrm{ml})$

\begin{tabular}{|c|c|c|c|}
\hline $\begin{array}{l}\text { Microorganism/ } \\
\text { Concentration }(\mu \mathrm{g} / \mathrm{ml})\end{array}$ & Growth rate (abs.) & $\begin{array}{l}\text { Stationary } \\
\text { phase (abs.) }\end{array}$ & Lag phase (h) \\
\hline \multicolumn{4}{|l|}{ S. aureus } \\
\hline Negative control & $0.31 \pm 0.01^{\mathrm{a}}$ & $2.51 \pm 0.06^{\mathrm{a}}$ & $5: 59: 20 \pm 0: 03: 03^{c d}$ \\
\hline 1.50 & $0.30 \pm 0.01^{a}$ & $2.51 \pm 0.04^{\mathrm{a}}$ & $5: 56: 20 \pm 0: 15: 32^{d}$ \\
\hline 3.75 & $0.31 \pm 0.01^{a}$ & $2.51 \pm 0.03^{\mathrm{a}}$ & $6: 14: 40 \pm 0: 10: 01^{b b c}$ \\
\hline 7.50 & $0.32 \pm 0.00^{\mathrm{a}}$ & $2.48 \pm 0.03^{\mathrm{a}}$ & $6: 18: 20 \pm 0: 08: 23^{b b c}$ \\
\hline 15.00 & $0.31 \pm 0.01^{a}$ & $2.51 \pm 0.02^{\mathrm{a}}$ & $6: 26: 00 \pm 0: 08: 40^{b c}$ \\
\hline 30.00 & $0.31 \pm 0.01^{\mathrm{a}}$ & $2.49 \pm 0.05^{\mathrm{a}}$ & $6: 34: 40 \pm 0: 03: 13^{b}$ \\
\hline 60.00 & $0.30 \pm 0.02^{\mathrm{a}}$ & $2.50 \pm 0.05^{a}$ & $6: 34: 40 \pm 0: 19: 01^{\mathrm{b}}$ \\
\hline 75.00 & $0.31 \pm 0.02^{\mathrm{a}}$ & $2.48 \pm 0.02^{\mathrm{a}}$ & $6: 39: 40 \pm 0: 28: 27^{b}$ \\
\hline Positive control & $0.01 \pm 0.00^{\mathrm{b}}$ & $0.10 \pm 0.00^{\mathrm{b}}$ & $8: 43: 40 \pm 0: 22: 11^{a}$ \\
\hline \multicolumn{4}{|l|}{ E. faecalis } \\
\hline Negative control & $0.57 \pm 0.04^{\mathrm{a}}$ & $1.57 \pm 0.02^{\mathrm{a}}$ & $5: 51: 40 \pm 0: 03: 13^{a}$ \\
\hline 1.50 & $0.53 \pm 0.06^{a}$ & $1.56 \pm 0.01^{a}$ & $5: 53: 00 \pm 0: 05: 34^{a}$ \\
\hline 3.75 & $0.54 \pm 0.02^{\mathrm{a}}$ & $1.55 \pm 0.01^{\mathrm{abc}}$ & $5: 57: 00 \pm 0: 02: 00^{a}$ \\
\hline 7.50 & $0.53 \pm 0.02^{\mathrm{a}}$ & $1.53 \pm 0.01^{b c}$ & $5: 56: 00 \pm 0: 02: 00^{a}$ \\
\hline 15.00 & $0.52 \pm 0.03^{\mathrm{ab}}$ & $1.52 \pm 0.02^{\mathrm{bc}}$ & $5: 58: 20 \pm 0: 04: 02^{a}$ \\
\hline 30.00 & $0.51 \pm 0.06^{\mathrm{ab}}$ & $1.52 \pm 0.01^{\mathrm{c}}$ & $5: 58: 20 \pm 0: 01: 09^{a}$ \\
\hline 60.00 & $0.44 \pm 0.05^{\mathrm{bc}}$ & $1.52 \pm 0.03^{\mathrm{bc}}$ & $5: 56: 00 \pm 0: 06: 15^{a}$ \\
\hline 75.00 & $0.38 \pm 0.04^{c}$ & $1.52 \pm 0.01^{\mathrm{C}}$ & $5: 57: 40 \pm 0: 10: 58^{a}$ \\
\hline Positive control & $-0.01 \pm 0.01^{d}$ & $0.30 \pm 0.01^{d}$ & $1: 21: 40 \pm 2: 21: 27^{b}$ \\
\hline \multicolumn{4}{|l|}{ E. coli } \\
\hline Negative control & $0.32 \pm 0.03^{\mathrm{ab}}$ & $2.09 \pm 0.02^{\mathrm{a}}$ & $5: 34: 40 \pm 0: 14: 22^{b}$ \\
\hline 1.50 & $0.37 \pm 0.04^{\mathrm{a}}$ & $2.01 \pm 0.01^{b c}$ & $6: 00: 20 \pm 0: 17: 09^{b}$ \\
\hline 3.75 & $0.36 \pm 0.09^{\mathrm{a}}$ & $2.02 \pm 0.05^{\mathrm{abc}}$ & $5: 57: 20 \pm 0: 32: 08^{b}$ \\
\hline 7.50 & $0.32 \pm 0.03^{a}$ & $2.02 \pm 0.05^{\mathrm{abc}}$ & $5: 49: 00 \pm 0: 18: 15^{b}$ \\
\hline 15.00 & $0.35 \pm 0.10^{\mathrm{a}}$ & $2.01 \pm 0.05^{\mathrm{bc}}$ & $5: 54: 40 \pm 0: 43: 25^{b}$ \\
\hline 30.00 & $0.54 \pm 0.38^{\mathrm{a}}$ & $1.98 \pm 0.05^{\mathrm{bc}}$ & $6: 42: 40 \pm 1: 32: 05^{b}$ \\
\hline 60.00 & $0.45 \pm 0.16^{\mathrm{a}}$ & $1.96 \pm 0.06^{c}$ & $6: 46: 20 \pm 0: 47: 00^{b}$ \\
\hline 75.00 & $0.34 \pm 0.03^{a}$ & $2.06 \pm 0.05^{\mathrm{ab}}$ & $7: 03: 40 \pm 0: 49: 54^{b}$ \\
\hline Positive control & $0.04 \pm 0.04^{\mathrm{b}}$ & $0.09 \pm 0.00^{d}$ & $10: 26: 00 \pm 0: 54: 35^{a}$ \\
\hline \multicolumn{4}{|l|}{ S. Typhimurium } \\
\hline Negative control & $0.19 \pm 0.00^{\mathrm{a}}$ & $2.50 \pm 0.00^{\mathrm{a}}$ & $2: 47: 00 \pm 0: 06: 56^{\mathrm{b}}$ \\
\hline 1.50 & $0.20 \pm 0.00^{a}$ & $2.48 \pm 0.01^{\mathrm{ab}}$ & $2: 52: 20 \pm 0: 14: 11^{b}$ \\
\hline 3.75 & $0.19 \pm 0.00^{\mathrm{a}}$ & $2.48 \pm 0.01^{b}$ & $2: 51: 20 \pm 0: 03: 03^{b}$ \\
\hline 7.50 & $0.19 \pm 0.00^{\mathrm{a}}$ & $2.47 \pm 0.01^{b}$ & $2: 58: 00 \pm 0: 13: 45^{b}$ \\
\hline 15.00 & $0.20 \pm 0.00^{\mathrm{a}}$ & $2.36 \pm 0.02^{c}$ & $3: 02: 40 \pm 0: 06: 30^{b}$ \\
\hline 30.00 & $0.20 \pm 0.00^{\mathrm{a}}$ & $2.33 \pm 0.10^{c}$ & $3: 05: 20 \pm 0: 11: 35^{b}$ \\
\hline 60.00 & $0.19 \pm 0.00^{\mathrm{a}}$ & $2.32 \pm 0.06^{c}$ & $2: 55: 40 \pm 0: 09: 37^{b}$ \\
\hline 75.00 & $0.20 \pm 0.01^{\mathrm{a}}$ & $2.25 \pm 0.08^{\mathrm{c}}$ & $3: 27: 20 \pm 0: 14: 34^{b}$ \\
\hline Positive control & $0.15 \pm 0.02^{b}$ & $2.00 \pm 0.00^{d}$ & $11: 42: 20 \pm 2: 27: 33^{a}$ \\
\hline
\end{tabular}

Mean values followed by the same letter ( $a, b, c$ or $d)$ within the same column do not differ significantly, as indicated by Duncan and Kruskal-Wallis (S. Typhimurium) tests $(p>0.05)$. 
integrity of cell membranes, inducing or increasing cell permeability, causing death (Durán et al., 2016; Zhang et al., 2016).

The low inhibition observed concerning E. faecalis may be related to its membrane structure and ability to form biofilms, which renders it more resistant to phagocytosis, antibodies, and antimicrobial agents (Alabdulmohsen and Saad, 2017). In contrast, Wu et al. (2014) pointed out that the excellent performance of AgNPs against E. faecalis depends not only on the concentration of both species but also on the interaction time.

Furthermore, it was verified that the higher the AgNPs' concentration in the sample, the greater the inhibition, suggesting an improved antimicrobial effect of AgNP-added LDPE films. This outcome is similar to that observed by Ruparelia et al. (2008), who studied the biocidal effect of AgNPs against E. coli and S. aureus.

Shake-flask assay. The results obtained from the shake-flask assays show that the nanostructured films influence the growth kinetics of $S$. aureus, E. faecalis, $E$. coli, and $S$. Typhimurium. These results are presented in Table 6.

Regarding the growth rate, only E. faecalis demonstrates a significant difference from the negative control $(\mathrm{p} \leq 0.05)$ at $60.00 \mu \mathrm{g} / \mathrm{ml}$, suggesting that AgNPs' addition to the films supports the reduction in the growth rate of such bacterium.

As for the maximum concentration at the stationary phase, it is observed that the nanostructured samples lead to decreased bacterial counts, although only $E$. faecalis, E. coli, and $S$. Typhimurium appear significantly different $(\mathrm{p} \leq 0.05)$ from the negative control at concentrations $7.50,1.50$, and $3.75 \mu \mathrm{g} / \mathrm{ml}$, respectively. These results indicate that the lowest concentrations are more effective in reducing the counts of Gram-negative bacteria (E. coli and $S$. Typhimurium). Jokar et al. (2012) reported a similar outcome, according to which AgNPs reduced $S$. aureus and E. coli counts by 23.3 and $27.3 \%$, respectively.

The lag phase is observed to last longer upon AgNPs' addition to LDPE-based films, corroborating the previously published results (Jokar et al., 2012; Kim et al., 2011; Sadeghnejad et al., 2014). S. aureus, notably, demonstrates a significant difference $(\mathrm{p} \leq 0.05)$ from the negative control at $30.00 \mu \mathrm{g} / \mathrm{ml}$ and higher, suggesting that an average concentration may provide a more prolonged lag phase for the growth of $S$. aureus.

It is clear from the aforementioned analyses that nanostructured films inhibited the growth and reproduction of bacterial cells in the early stages. This observation is in line with the results of Sadeghnejad et al. (2014), who investigated the antimicrobial action of AgNP-added polyethylene films against $S$. aureus and $E$. coli using the shake-flash assays. They discovered that AgNPs influence the lag and log phases of both bacteria. Additionally, it was evidenced that the higher the AgNPs concentration $(\mu \mathrm{g} / \mathrm{ml})$ in LDPE-based films, the greater its influence on the growth kinetics of the studied bacteria. A similar outcome was observed by Jokar et al. (2012), who studied the effect of AgNPs on LDPE films using shake-flask assays. They also noticed that nanocomposites comprising low AgNPs contents did not alter the growth kinetics of $S$. aureus and E. coli.

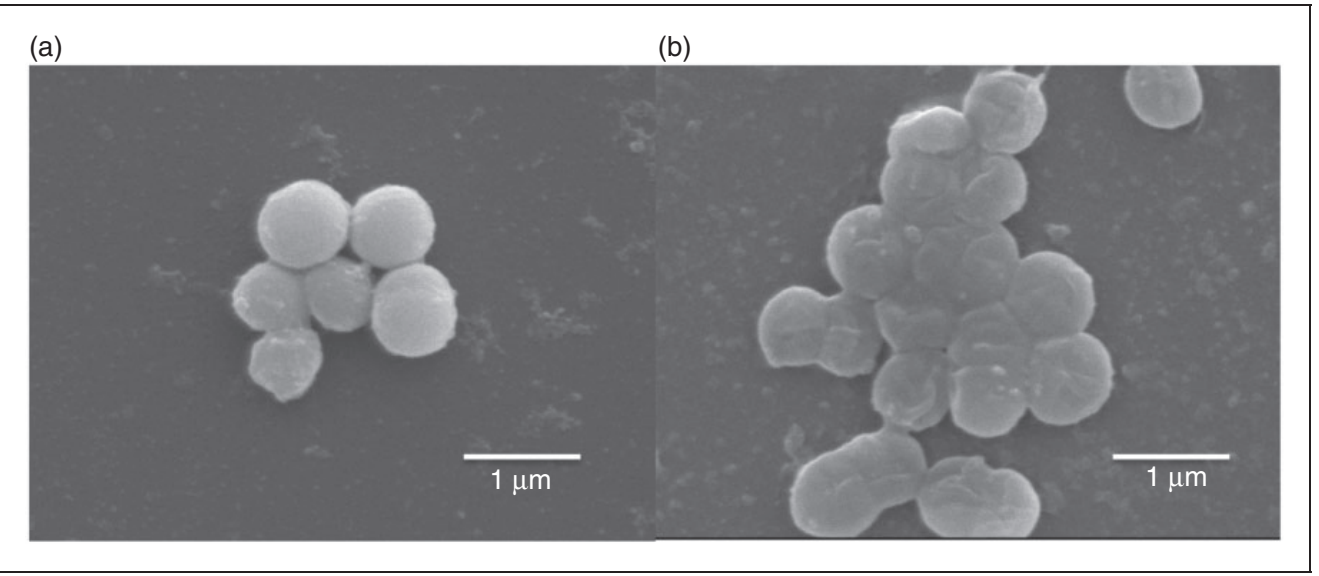

Figure 7. S. aureus treated with control (a) and nanostructured $(75.00 \mu \mathrm{g} / \mathrm{ml})$ (b) LDPE-based films. 


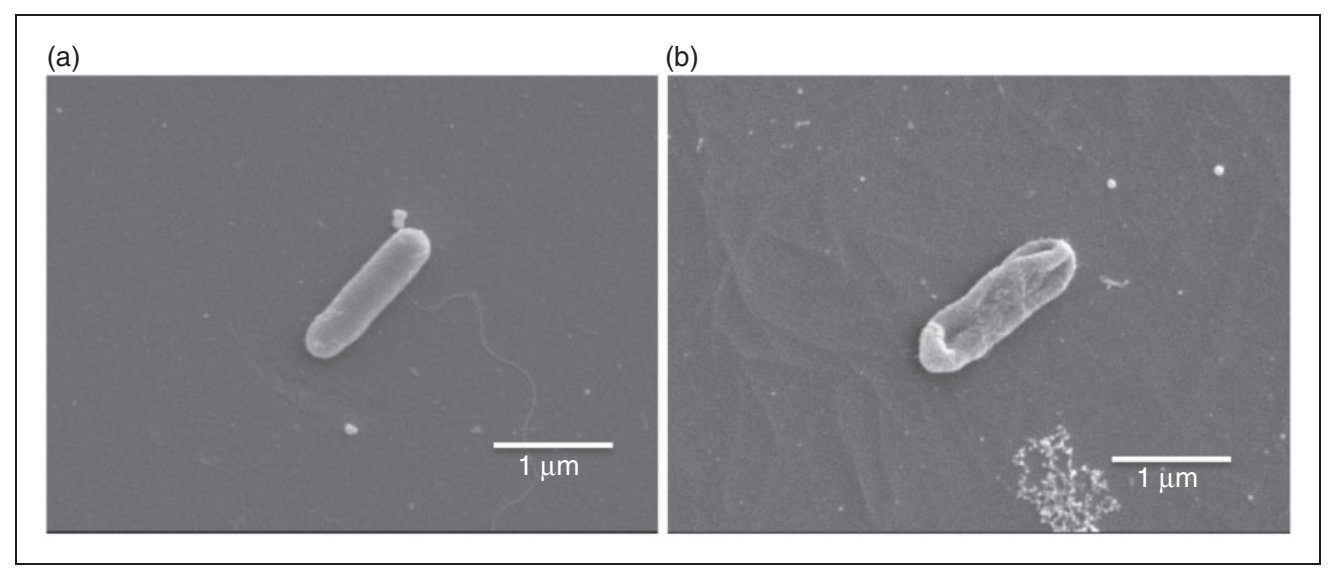

Figure 8. E. coli treated with control (a) and nanostructured $(75.00 \mu \mathrm{g} / \mathrm{ml})$ (b) LDPE-based films.

Bacterial images from SEM. S. aureus and E. coli were imaged after being in contact with the control and nanostructured films $(75.00 \mu \mathrm{g} / \mathrm{ml})$; these images are shown in Figures 7 and 8, respectively. Both present bacteria alteration of the microbial wall structure upon treatment with AgNP-enriched LDPE films.

The mechanism of action of AgNPs as an antimicrobial agent has not been completely elucidated yet, although some models have already been proposed (Prabhu and Poulose, 2012). Sondi and SalopekSondi (2004) verified using SEM that the surface of the bacterial cell wall upon contact with the AgNPs conceivably promotes structural changes in the wall structure (e.g. increase permeability), thereby impairing the ability of the bacterial cells in suitably regulating the transport across the plasma membrane and ultimately causing cell death.

The critical changes to the membrane structure observed in AgNP-treated bacteria (Figures 7(b) and 8(b)) may be a consequence of the ability of silver nanoparticles to anchor in the cell wall and accumulate to form "pits" on the cell surface. Silver nanoparticles, after contact with the cell membrane surface, suffer a change in their respiration, because silver interacts with the enzymes of the microorganisms, which can cause a degradation of the membrane structure (Prabhu and Poulose, 2012; Raffi et al., 2008).

\section{CONCLUSION}

It is established from this study that the addition of AgNPs into LDPE films interfered neither in the physicochemical nor thermal properties of the latter. LDPE/AgNPs films were effective in inhibiting the growth of the investigated microorganisms. AgNPs exhibited a more significant antimicrobial action against Gram-negative bacteria and fungi than Grampositive bacteria. These results demonstrated the potential of extruding LDPE films after being incorporated with AgNPs for producing antimicrobial food packaging, especially for liquid foods. It was verified through microbiological evaluations using direct contact antimicrobial activity and shake-flask assays that such films can lead to diminishing contamination risks and maintaining food quality.

\section{ACKNOWLEDGEMENTS}

The authors are grateful to Universidade Estadual Paulista "Júlio de Mesquita Filho" (UNESP), and Empresa Brasileira de Pesquisa Agropecuária (EMBRAPA, project 13.16.04.041.00.00) for financial and technical support.

\section{DECLARATION OF CONFLICTING INTERESTS}

The author(s) declared no potential conflicts of interest with respect to the research, authorship, and/or publication of this article.

\section{FUNDING}

The author(s) received no financial support for the research, authorship, and/or publication of this article: The author(s) received financial support for this research from Coordenação de Aperfeiçoamento de Pessoal de Nível Superior-Brasil (CAPES)_Finance Code 1633026, Conselho Nacional de Desenvolvimento Cientifico e Tecnológico (CNPq), Fundação de Amparo á Pesquisa do Estado de São Paulo (FAPESP) and Empresa Brasileira de Pesquisa Agropecuária (EMBRAPA, project 13.16.04.041.00.00).

\section{ORCID iDs}

Sabrina da Costa Brito (D) https://orcid.org/0000-0002-0868254X

Marcos D Ferreira (D) https://orcid.org/0000-0003-4544-8784

\section{REFERENCES}

Abdel-Mohsen AM, Abdel-Rahman RM, Fouda MMG, Vojtova L, Uhrova L, Hassan AF, et al. (2014). 
Preparation, characterization and cytotoxicity of schizophyllan/silver nanoparticle composite. Carbohydrate Polymers 102: 238-245.

Akter M, Sikder MT, Rahman MM, Ullah AKMA, Hossain KFB, Banik S, et al. (2018). A systematic review on silver nanoparticles-induced cytotoxicity: Physicochemical properties and perspectives. Journal of Advanced Research 9: 1-16.

Alabdulmohsen ZA and Saad AY. (2017). Antibacterial effect of silver nanoparticles against Enterococcus faecalis. Saudi Endodontic Journal 7(1): 29.

Avila-Sosa R, Hernández-Zamoran E, López-Mendoza I, Palou E, Munguía MTJ, Nevárez-Moorillón GV and López-Malo A. (2010). Fungal inactivation by mexican oregano (lippia berlandieri schauer) essential oil added to amaranth, chitosan, or starch edible films. Journal of Food Science 75(3): 127-133.

Becaro AA, Puti FC, Correa DS, Paris EC, Marconcini JM and Ferreira MD. (2015). Polyethylene films containing silver nanoparticles for applications in food packaging: Characterization of physico-chemical and anti-microbial properties. Journal of Nanoscience and Nanotechnology 15(3): 2148-2156.

Becaro AA, Puti FC, Panosso AR, Gern JC, Brandão HM, Correa DS, et al. (2016). Postharvest quality of fresh-cut carrots packaged in plastic films containing silver nanoparticles. Food and Bioprocess Technology 9(4): 637-649.

Boschetto DL, Lerin L, Cansian R, Pergher SBC and Di Luccio M. (2012). Preparation and antimicrobial activity of polyethylene composite films with silver exchanged zeolite-Y. Chemical Engineering Journal 204-205: 210-216.

Brody AL, Bugusu B, Han JH, Sand CK and McHugh TH. (2008). Innovative food packaging solutions. Journal of Food Science 73(8): 107-116.

Canevarolo SV. (2017). Microscópia Eletrônica da Varredura. In: SV Canevarolo (ed.), Técnicas de Caracterização de Polímeros, 3rd edn, Artliber, São Paulo, p. 448.

Carbone M, Donia DT, Sabbatella G and Antiochia R. (2016). Silver nanoparticles in polymeric matrices for fresh food packaging. Journal of King Saud University Science 28(4): 273-279.

Chaudhry Q, Scotter M, Blackburn J, Ross B, Boxall A, Castle L, et al. (2008). Applications and implications of nanotechnologies for the food sector. Food Additives and Contaminants - Part A Chemistry, Analysis, Control, Exposure and Risk Assessment 25(3): 241-258.

Chen X and Schluesener HJ. (2008). Nanosilver: A nanoproduct in medical application. Toxicology Letters 176(1): $1-12$.

Damm C, Neumann M and Münstedt H. (2005). Properties of nanosilver coatings on polymethyl methacrylate. Soft Materials 3(2-3): 71-88.

Dehnavi A, Aroujalian A, Raisi A and Fazel S. (2012). Preparation and characterization of polyethylene/silver nanocomposite films with antibacterial activity. Journal of Applied Polymer Science 127(2): 1180-1190.

Del Nobile MA, Conte A, Buonocore GG, Incoronato AL, Massaro A and Panza O. (2009). Active packaging by extrusion processing of recyclable and biodegradable polymers. Journal of Food Engineering 93(1): 1-6.

Duncan TV. (2011). Applications of nanotechnology in food packaging and food safety: Barrier materials, antimicrobials and sensors. Journal of Colloid and Interface Science 363(1): 1-24.

Durán N, Durán M, de Jesus MB, Seabra AB, Fávaro WJ and Nakazato G. (2016). Silver nanoparticles: A new view on mechanistic aspects on antimicrobial activity. Nanomedicine: Nanotechnology, Biology, and Medicine 12(3): 789-799.

Emamifar A, Kadivar M, Shahedi M and Solimanian-Zad S. (2011). Effect of nanocomposite packaging containing Ag and $\mathrm{ZnO}$ on reducing pasteurization temperature of orange juice. Journal of Food Processing and Preservation 36(2): 104-112.

Franci G, Falanga A, Galdiero S, Palomba L, Rai M, Morelli $\mathrm{G}$, et al. (2015). Silver nanoparticles as potential antibacterial agents. Molecules 20(5): 8856-8874.

Gava AJ, Silva CAB and Frias JRG. (2008). Embalagem de Alimentos. In: AJ Gava (ed.) Tecnologia de Alimentos: Princípios e Aplicações. 2nd edn, Nobel, São Paulo, pp. 105-127.

Gowri LAVS, Amorim T, Carneiro N, Souto AP and Esteves MF. (2011). Novel copolymer for $\mathrm{SiO}_{2}$ nanoparticles dispersion. Journal of Applied Polymer Science 124: 1553-1561.

Greiner R. (2009). Current and projected applications of nanotechnology in the food sector. Nutrire: Journal of the Brazilian Society for Food and Nutrition 34(1): 243-260.

Huang R, Hou B, Li H, Fu X and Xie C. (2015). RSC advances preparation of silver nanoparticles supported mesoporous silica microspheres with perpendicularly aligned mesopore channels and their antibacterial activities. RSC Advances 5: 61184-61190.

Jokar M, Abdul Rahman R, Ibrahim NA, Abdullah LC and Tan CP. (2012). Melt production and antimicrobial efficiency of low-density polyethylene (LDPE)-silver nanocomposite film. Food and Bioprocess Technology 5(2): 719-728.

Kim JS, Kuk E, Yu KN, Kim JH, Park SJ, Lee HJ, et al. (2007). Antimicrobial effects of silver nanoparticles. Nanomedicine: Nanotechnology, Biology, and Medicine 3(1): 95-101.

Kim S, Lee H and Ryu D. (2011). Antibacterial activity of silver-nanoparticles against Staphylococcus aureus and Escherichia coli. Korean Journal of Microbiology 39(1): 77-85.

Lacerda Júnior O. da S, Cavalcanti RM, Matos TM, Venâncio J. de B, Barros IB, Veiga-Júnior VF, et al. (2013). Síntese do material mesoporoso mcm-41 usando esponja de água-doce como fonte de sílica. Química Nova 36(9): 1348-1353.

LeBourvellec G, Monnerie L and Jarry JP. (1986). Amorphous orientation and induced crystallization in uniaxially stretched poly(ethylene terephthalate glycol). Polymer 27(6): 856-860.

Liu F, Liu H, Li X, Zhao H, Zhu D, Zheng Y, et al. (2012). Nano-TiO ${ }_{2} @ A g / P V C$ film with enhanced antibacterial 
activities and photocatalytic properties. Applied Surface Science 258(10): 4667-4671.

Madani M. (2011). Structure, optical and thermal decomposition characters of LDPE graft copolymers synthesized by gamma irradiation. Current Applied Physics 11(1): 70-76.

Marsh K and Bugusu B. (2007). Food packaging - Roles, materials, and environmental issues: Scientific status summary. Journal of Food Science 72(3): 39-55.

Mihindukulasuriya S and Lim L. (2014). Nanotechnology development in food packaging: A review. Trends in Food Science \& Technology 40(2): 149-167.

Miranda VR and Carvalho AJF. (2011). Blendas compatíveis de amido termoplástico e polietileno de baixa densidade compatibilizadas com ácido cítrico. Polímeros 21(5): 353-360.

Mirzajani F, Ghassempour A, Aliahmadi A and Esmaeili MA. (2011). Antibacterial effect of silver nanoparticles on Staphylococcus aureus. Research in Microbiology 162(5): 542-549.

Mishra AK and Luyt AS. (2008). Effect of sol-gel derived nano-silica and organic peroxide on the thermal and mechanical properties of low-density polyethylene/wood flour composites. Polymer Degradation and Stability 93(1): 1-8.

Motaung T, Mochane M, Makhetha T, Motloung S, Mokhothu T, Mokhena T, et al. (2017). Effect of mechanical treatment on morphology and thermal and mechanical properties of sugar cane bagasse-low-density polyethylene composites. Polymer Composites 38(8): 1497-1503.

Olmos D, Martínez-Tarifa JM, González-Gaitano G and González-Benito J. (2012). Uniformly dispersed submicrometre $\mathrm{BaTiO}_{3}$ particles in PS based composites. Morphology, structure and dielectric properties. Polymer Testing 31(8): 1121-1130.

Pagno CH, Costa TMH, De Menezes EW, Benvenutti EV, Hertz PF, Matte CR, et al. (2015). Development of active biofilms of quinoa (Chenopodium quinoa W.) starch containing gold nanoparticles and evaluation of antimicrobial activity. Food Chemistry 173: 755-762.

Pérez MA, Rivas BL, Garrido-Miranda KA, CamposRequena VH, Martínez M, Castaño J, et al. (2014). Low density polyethylene (LDPE) nanocomposites with passive and active barrier properties. Journal of the Chilean Chemical Society 59(2): 2442-2446.

Piringer OG and Baner AL. (2000). Preservation of quality through packaging. In: Piringer OG and Baner AL (eds) Plastic Packaging Materials for Food: Barrier Function, Mass Transport, Quality Assurance, and Legislation. 1st ed. Weinheim: Wiley-VCH, pp. 4-8.

Prabhu S and Poulose EK. (2012). Silver nanoparticles: Mechanism of antimicrobial action, synthesis, medical applications, and toxicity effects. International Nano Letters 2(1): 32.

Puti FC, Becaro AA, Correa DS and Ferreira MD. (2014). Caracterização físico-química e microbiológica de filmes de PEBD com nanopartículas para aplicação como embalagens para alimentos. In: CMP Vaz, DMBP Milori and S. Crestana (eds) Anais do SIAGRO: Ciência, Inovação e
Mercado 2014, vol. 1, Embrapa Instrumentação, São Carlos/SP, pp. 391-394.

Qasim M, Singh BR, Naqvi AH, Paik P and Das D. (2015). Silver nanoparticles embedded mesoporous $\mathrm{SiO}_{2}$ nanosphere: An effective anticandidal agent against Candida albicans 077. Nanotechnology 26(28): 285102.

Raffi M, Hussain F, Bhatti TM, Akhter JI, Hameed A and Hasan MM. (2008). Antibacterial characterization of silver nanoparticles against E. coli ATCC-15224. Journal of Materials Science and Technology 24(2): 192-196.

Rajandas H, Parimannan S, Sathasivam K, Ravichandran M and $\mathrm{Su}$ Yin L. (2012). A novel FTIR-ATR spectroscopy based technique for the estimation of low-density polyethylene biodegradation. Polymer Testing 31(8): 1094-1099.

Ruparelia JP, Chatterjee AK, Duttagupta SP and Mukherji S. (2008). Strain specificity in antimicrobial activity of silver and copper nanoparticles. Acta Biomaterialia 4(3): 707-716.

Sadeghnejad A, Aroujalian A, Raisi A and Fazel S. (2014). Antibacterial nano silver coating on the surface of polyethylene films using corona discharge. Surface and Coatings Technology 245: 1-8.

Siddiqi KS, Husen A and Rao RAK. (2018). A review on biosynthesis of silver nanoparticles and their biocidal properties. Journal of Nanobiotechnology 16(1).

Sondi I and Salopek-Sondi B. (2004). Silver nanoparticles as antimicrobial agent: A case study on E. coli as a model for Gram-negative bacteria. Journal of Colloid and Interface Science 275(1): 177-182.

Spricigo PC, Trento JP and Bresolin JD. (2015). Methods of preparing flower stem samples for scanning electron microscopy. Advances in Ornamental Horticulture and Landscaping 21(1): 17-26.

Tannous J, Keller NP, Atoui A, El Khoury A, Lteif R, Oswald IP, et al. (2018). Secondary metabolism in Penicillium expansum: Emphasis on recent advances in patulin research. Critical Reviews in Food Science and Nutrition 58(12): 2082-2098.

Wróblewska-Krepsztul J, Rydzkowski T, Borowski G, Szczypiński M, Klepka T and Thakur VK. (2018). Recent progress in biodegradable polymers and nanocomposite-based packaging materials for sustainable environment. International Journal of Polymer Analysis and Characterization 23(4): 383-395.

Wu D, Fan W, Kishen A, Gutmann JL and Fan B. (2014). Evaluation of the antibacterial efficacy of silver nanoparticles against Enterococcus faecalis biofilm. Journal of Endodontics 40(2): 285-290.

Xia X, Cai S and Xie C. (2006). Water absorption characteristics of novel $\mathrm{Cu} / \mathrm{LDPE}$ nanocomposite for use in intrauterine devices. Journal of Biomedical Materials Research. Part B, Applied Biomaterials 79(2): 345-352.

Youssef AM and El-Sayed SM. (2018). Bionanocomposites materials for food packaging applications: Concepts and future outlook. Carbohydrate Polymers 193: 19-27.

Zhang C, Hu Z and Deng B. (2016). Silver nanoparticles in aquatic environments: Physiochemical behavior and antimicrobial mechanisms. Water Research 88: 403-427. 